Jurnal Progres Ekonomi Pembangunan (JPEP)

Volume 5, Nomor 1, Tahun 2020

Page: 47- 57

http://ojs.uho.ac.id/index.php/JPEP

\title{
PENGARUH DANA BOS TERHADAP KINERJA SEKOLAH STUDI PADA SMK KABUPATEN KONAWE
}

\author{
Kartowiyono \\ Program Ilmu Ekonomi Pascasarjana Universitas Halu Oleo Kendari \\ Email: kartowiyono@yahoo.co.id \\ Rosnawintang \\ Fakultas Ekonomi dan Bisnis Universitas Halu Oleo Kendari \\ Email: nanarosnawintang @yahoo.co.id \\ Erwin Hadisantoso \\ Fakultas Ekonomi dan Bisnis Universitas Halu Oleo Kendari \\ Email: erwinhadisantoso@yahoo.co.id
}

\begin{abstract}
ABSTRAK
Penelitian ini bertujuan untuk menguji dan menganalisis pengaruh Dana BOS terhadap Kinerja Sekolah. Studi pada SMK Kabupaten Konawe. Penelitian ini menggunakan pendekatan kuantitatif. Populasi dalam penelitian ini adalah pihak yang secara langsung memiliki peran yang menentukan keberhasilan implementasi program Bantuan Operasional Sekolah di 11 SMK Kabupaten Konawe, yaitu Pendidik, Tenaga Kependidikan, OSIS dan Pengurus Komite.

Penelitian ini merupakan penelitian kuantitatif. Metode pengumpulan datanya menggunakan kuesioner. Sedangkan untuk metode analisis data menggunakan analisis statistik deskriptif dan uji kualitas data menggunakan uji reliabilitas dan uji validitas serta peneliti menggunakan uji asumsi klasik. Analisis data diolah dengan bantuan Software IBM SPSS 24. Hasil penelitian menunjukkan bahwa (1) kecukupan dana BOS berpengaruh positif dan signifikan terhadap kinerja sekolah, (2) ketepatan dana BOS berpengaruh positif dan signifikan terhadap kinerja sekolah, (3) kesesuaian dana BOS berpengaruh positif dan signifikan terhadap kinerja sekolah.
\end{abstract}

\section{Kata Kunci: Kecukupan, Ketepatan, Kesesuaian, Kinerja Sekolah}

\section{ABSTRACT}

This study aims to examine and analyze the effect of the BOS Fund on School Performance. Study at Vocational Schools in Konawe Regency. This research is using a quantitative approach. The population in this study are those who directly have a role in determining the successful implementation of the School Operational Assistance program in 11 Vocational schools in Konawe Regency, namely Educators, Education Personnel, OSIS and Committee Managers.

This research is a quantitative research. The data collection method is using questionnaire. As for the method of data analysis using descriptive statistical analysis and data quality tests using the reliability test and validity test as well as researchers using the classic assumption test. Data analysis was processed with the help of IBM SPSS 24 Software. The results showed that (1) the adequacy of BOS funds had a positive and significant effect on school performance, (2) the accuracy of BOS funds had a positive and significant effect on school performance, (3) the suitability of BOS funds has a positive and significant impact on school performance.

Keywords: Adequacy, Accuracy, Conformity, School Performance 
Jurnal Progres Ekonomi Pembangunan (JPEP)

Volume 5, Nomor 1, Tahun 2020

Page: 47- 57

http://ojs.uho.ac.id/index.php/JPEP

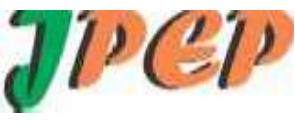

e-ISSN: 2052-5171

\section{PENDAHULUAN}

Sekolah merupakan organisasi yang kompleks dan unik. Dikatakan kompleks karena di dalam sekolah terdapat sumberdaya-sumberdaya yang saling terkait, sedangkan unik karena sekolah menjadi tempat proses belajar-mengajar dan pembudaya kehidupan umat manusia. Untuk dapat mencapai tujuan sekolah, diperlukan pemimpin yang mampu mendayagunakan sumberdaya-sumberdaya tersebut agar dapat dimanfaatkan semaksimal mungkin (Hendarman, 2018).

Selain unsur kepala sekolah dan guru-guru yang kompeten, tenaga kependidikan, peserta didik dan stakeholder yang tergabung dalam komite sekolah dan dewan pendidikan pun sangat berperan dalam membantu meningkatkan kinerja sekolah. keseluruhan peran tersebut dalam konteks pendidikan disebut dengan supply-side role, yakni peran perangkat sekolah dari sudut kebutuhan akan peningkatan kinerja sekolah. Peran yang juga penting dalam penyelenggaran sekolah bermutu adalah peran anggaran atau demand-side role dari sudut sinergitas penyelenggaran pendidikan di sekolah, sehingga mampu meningkatkan kinerja sekolah itu sendiri (Badallah, 2017). Dalam konteks peran anggaran sebagai aspek demand-side role, bantuan operasional sekolah menjadi salah satu program kegiatan dan anggaran yang diberikan pemerintah dalam rangka meningkatkan kinerja sekolah. Aspek penting bantuan operasional sekolah sebagai aspek demand-side role, yakni: 1) Ketepatan dana, yakni bagaimana ketepatan waktu penyaluran dan ketepatan sasaran pengalokasian dana bantuan operasional sekolah, 2) Kecukupan dana, yakni bagaimana dana bantuan operasional sekolah yang diberikan sesuai dengan kebutuhan sekolah penerima, 3) Kesesuaian penggunaan dana, yakni bagaimana sekolah menggunakan dana bantuan operasional sesuai dengan petunjuk teknis penggunaan dan sesuai dengan permintaan kebutuhan sekolah.

Program dan kegiatan BOS adalah program yang dilaksanakan oleh Kemendikbud RI dalam rangka membantu pengadaan buku teks pelajaran, pembiayaan seluruh kegiatan penerimaan siswa baru, pembiayaan kegiatan remedial, pakem, pembelajaran kontekstual, pengayaan, pemantapan persiapan ujian, olah raga, kesenian, karya ilmiah remaja, pramuka, palang merah remaja, usaha kesehatan sekolah, pembiayaan ulangan harian, ulangan umum, ujian sekolah, laporan hasil belajar, pembelian bahan habis pakai, pembiayaan langganan daya dan jasa, pembiayaan perawatan sekolah, pembayaran honorarium bulanan guru dan tenaga kependidikan honorer, pengembangan profesi guru, pembiayan biaya transportasi, seragam, sepatu, dan alat tulis sekolah bagi siswa kategori miskin atau tidak mampu, dan pembiayan pengelolaan bantuan operasional sekolah dan pembelian komputer dan printer. (Kemendikbud, 2014). Namun beberapa hasil penelitian terdapat pertentangan terkait ketepatan dana, kecukupan dana, dan kesesuaian penggunaan dana terhadap peningkatan kinerja sekolah. Sejalan dengan hasil penelitian terdahulu, kenyataan yang terjadi di SMK Kabupaten Konawe dalam penyaluran dana BOS antara lain: dana BOS menjadi tumpuan utama pembiayaan operasional sekolah, penyaluran yang tidak tepat waktu, kegiatan pembelajaran dan evaluasi terhambat, dan penyelenggaraan kegiatan praktek, uji kompetensi keahlian dan praktek kerja industri tidak sejalan dengan kesiapan dari segi pendanaan.

Mengingat pentingnya dana BOS untuk di kaji, banyak peneliti yang telah melakukan studi yang serupa dengan penelitian ini diantaranya : Diputra/2011, Asnawi/2013, Ningsih/2017, Soulisa/2017, Sedan/2013, Perdana/2016, Saputra/2017, dan lain-lain.

Penelitian ini bertujuan untuk menganalisis dan mengetahui: (1) pengaruh ketepatan dana bantuan operasional sekolah terhadap kinerja SMK di Kabupaten Konawe; (2) pengaruh kecukupan dana bantuan operasional sekolah terhadap kinerja SMK di Kabupaten Konawe; 
Jurnal Progres Ekonomi Pembangunan (JPEP)

Volume 5, Nomor 1, Tahun 2020

Page: 47- 57

http://ojs.uho.ac.id/index.php/JPEP

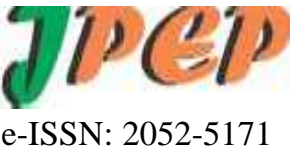

dan (3) pengaruh kesesuaian dana bantuan operasional sekolah berpengaruh signifikan terhadap kinerja SMK di Kabupaten Konawe.

\section{KAJIAN PUSTAKA DAN KERANGKA KONSEP}

Bantuan Operasional Sekolah

Bantuan operasional Sekolah (BOS) sekolah menengah adalah program pemerintah sebagai rintisan program wajib belajar 12 tahun yang terjangkau dan bermutu. Bantuan Operasional Sekolah disalurkan langsung ke SMA dan SMK (negeri maupun swasta) untuk membantu biaya operasional dan non-personalia. Perhitungan besaran BOS SMK yang diterima sekolah berdasarkan jumlah siswa dan satuan biaya bantuan (Dirjen Anggaran Kemenkeu, 2015). Hasil penelitian Dirjen Anggaran, Kemenkeu (2015), bahwa ketepatan dana BOS adalah persoalan bagaimana ketepatan waktu (efektivitas) penyaluran dana bantuan operasional sesuai dengan petunjuk teknis dan petunjuk pelaksanaan dana BOS. Asnawi (2013) menyatakan berkenaan dengan apakah kebijakan BOS tersebut mencapai hasil (akibat) yang diharapkan atau mencapai tujuan dari diadakannya kegiatan-kegiatan yang dilakukan. Efektifitas, yang secara dekat berhubungan dengan rasionalitas teknis, selalu diukur dari unit produk atau layanan atau nilai moneternya. Upaya tersebut dapat dilihat dari indikator hasil yang diharapkan dalam pelaksanaan program BOS. Kecukupan dana BOS yaitu suatu hasil pelaksanan BOS yang dilihat dari kesesuaian biaya dengan standard dan bentuk surat pertanggungjawaban yang sesuai dengan ketentuan petunjuk pelaksanaan dan petunjuk teknis pengelolaan dana BOS (Asnawi: 2013). Dalam konteks kecukupan dana BOS, Asnawi (2013) menyatakan kecukupan dana berkenaan dengan seberapa jauh suatu tingkat efektifitas memuaskan kebutuhan, nilai atau kesempatan menumbuhkan adanya masalah. Kriteria kecukupan menekankan pada kuatnya hubungan antara alternatif kebijakan dan hasil yang diharapkan. Kesesuaian penggunaan anggaran dana BOS berhubungan langsung dengan kemampuan pengelolaan anggaran itu sendiri. Marliyani, 2015 (dalam saputra, 2015) mengatakan bahwa kesesuaian penggunaan anggaran adalah bagaimana kemampuan sekolah dalam menyelaraskan kesesuaian rancangan kegiatan, kesesuaian kebutuhan sekolah dan kesesuaian laporan pertangungajawaban keuangan dengan ketentuan penggunaan anggaran danabantuan operasional sekolah.

\section{Kinerja Sekolah}

Kinerja merupakan hasil kerja secara kualitas dan kuantitas yang dapat dicapai oleh seseorang dalam melaksanakan tugas sesuai dengan tanggung jawab yang diberikan. Kinerja menurut Kusriyanto (dalam Mangkunegara, 2014) adalah perbandingan hasil yang dicapai dengan peran serta tenaga kerja persatuan waktu (lazimnya perjam). Gomes (dalam Mangkunegara, 2014) mengemukakan kinerja sebagai ungkapan seperti output, efisiensi serta efektivitas sering dihubungkan dengan produktivitas. Sementara kinerja menurut Mangkunegara (2014) adalah hasil kerja secara kualitas dan kuantitas yang dicapai oleh seseorang karyawan dalam melaksanakan tugasnya sesuai dengan tanggung jawab yang diberikan kepadanya. Mengginson (dalam Mangkunegara, 2014) mengatakan penilaian prestasi kerja (performance appraisal) adalah suatu proses yang digunakan pimpinan untuk menentukan apakah seorang karyawan melakukan pekerjaannya sesuai dengan tugas dan tanggung jawabnya. Selanjutnya Sikula (dalam Mangkunegara,2014) mengemukakan bahwa penilaian pegawai merupakan evaluasi yang sistematis dari pekerjaan pegawai dan potensi yang dapat dikembangkan. Penilaian dalam proses penafsiran atau penentuan nilai, kualitas atau status dari beberapa obyek orang ataupun sesuatu barang. Kinerja sekolah dapat dilihat dengan kefektifan sekolah tersebut. Sekolah yang menjalankan proses pendidikan sesuai dengan aturan yang telah direncanakan maka dapat dikatakan sekolah tersebut memiliki kinerja 
Jurnal Progres Ekonomi Pembangunan (JPEP)

Volume 5, Nomor 1, Tahun 2020

Page: 47- 57

http://ojs.uho.ac.id/index.php/JPEP

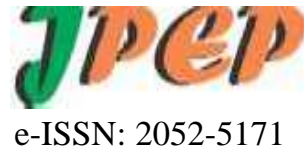

yang baik. Koontz (dalam Hendarman, 2018), menyatakan bahwa keefektifan diukur dengan tingkat keberhasilan dalam mencapai tujuan dengan kegiatan yang dilakukan. Kinerja sekolah dalam konteks kefektifan sekolah itu sendiri menurut Suwarto (dalam Hendarman, 2018), bahwa kefektifan berkaitan erat dengan pencapaian unjuk kerja secara maksimal, yaitu dalam arti pencapaian target yang berkaitan dengan kualitas, kuantitas dan waktu. Ammons (dalam Rasto, 2012) menjelaskan kinerja organisasi dapat diukur melalui kriteria workload, eficiency, effectiveness, dan productivity. Workload menunjukkan jumlah beban kerja yang diselesaikan. Eficiency menunjukkan perbandingan antara input dan output. Effectiveness menunjukkan perbandingan antara output dan outcome yaitu tingkat ketercapaian hasil akhir setelah output diperoleh. Productivity menunjukkan jumlah hasil yang dicapai pada kurun waktu tertentu. Dengan memperhatikan berbagai pendapat para ahli tentang dimensi pengukuran kinerja organisasi, maka pengukuran kinerja sekolah dalam penelitian ini merujuk kepada standar pendidikan nasional (PP Nomor 19 Tahun 2005). Berdasarkan asumsi di atas maka indikator kinerja sekolah menggunakan delapan standar pendidikan nasional yang dapat dijadikan rujukan untuk mengukur kinerja sekolah, sebagaimana tertuang dalam Pasal 2 Ayat (1), yaitu: Standar isi, Standar Proses, Standar Kompetensi Lulusan, Standar Pendidik dan Tenaga Kependidikan, Standar Penilaian, Standar Sarana dan Prasarana, Standar Pengelolaan dan Standar Pembiayaan.

\section{Kerangka Konsep}

Kerangka konseptual yang digunakan dalam penelitian ini merupakan kajian yang mendalam, baik berdasarkan teori maupun kajian empiris hubungan kausal ketepatan dana, kecukupan dana, kesesuaian penggunaan dana dan kinerja sekolah. Kerangka konseptual dibangun dari rumusan masalah, kajian literatur setiap variabel dan pola hubungan yang dibentuk oleh variabel tersebut. Beberapa penelitian terdahulu menunjukkan bahwa ketepatan dana, kecukupan dana dan kesesuaian penggunaan dana merupakan variabel independen dalam kinerja sekolah. Sehingga dapat dirumuskan kerangka konsep sebagai berikut:

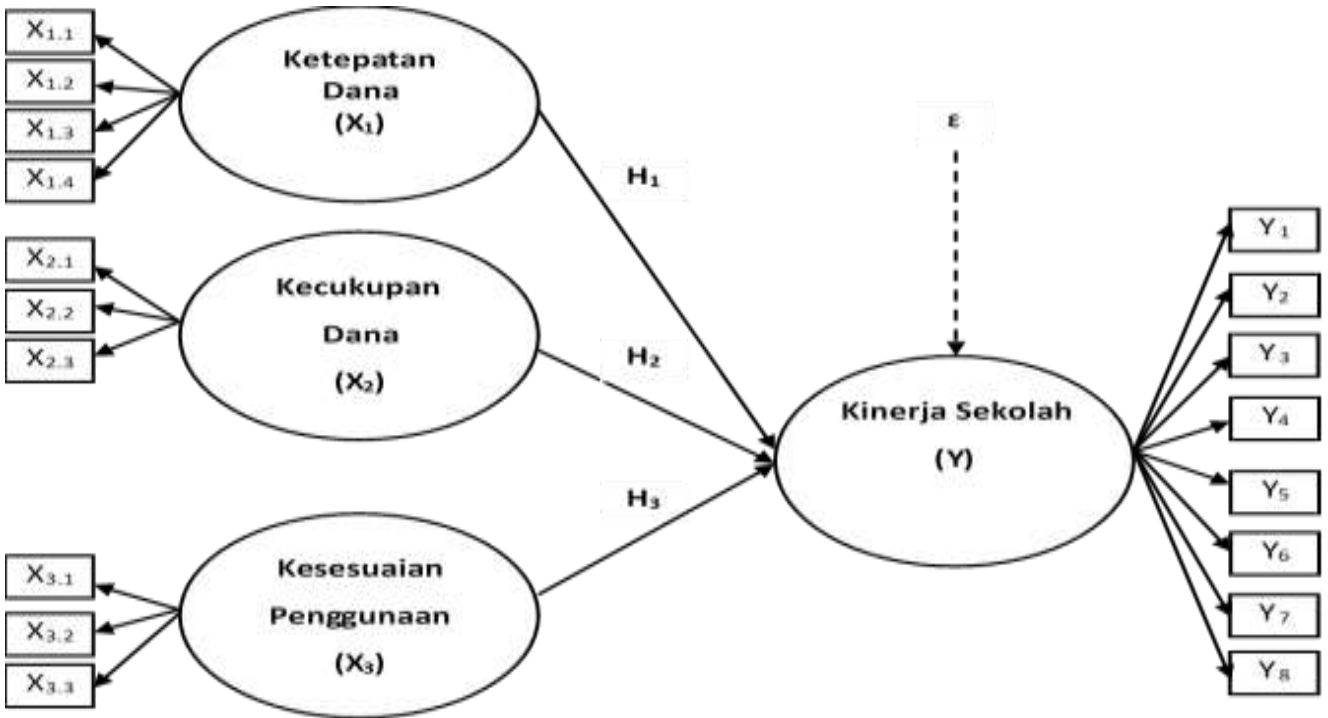

Gambar 1

Skema Kerangka Konsep 
Jurnal Progres Ekonomi Pembangunan (JPEP)

Volume 5, Nomor 1, Tahun 2020

Page: 47- 57

http://ojs.uho.ac.id/index.php/JPEP

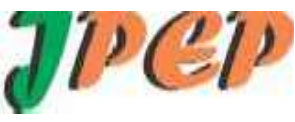

e-ISSN: 2052-5171

\section{METODE PENELITIAN}

Penelitian ini adalah Penelitian Ekplanasi (explanatory research) yaitu Penelitian yang bertujuan untuk menguji atau menjelaskan pengaruh antara variable yang dihipotesiskan. Variabel dalam penelitian ini terdiri dari variabel bebas dan variabel terikat. Dimana variabel bebas dalam penelitian ini adalah ketepatan dana (X1), kecukupan dana (X2), dan kesesuaian penggunaan dana (X3), sedangkan varibel terikatnya adalah kinerja sekolah (Y).

Penelitian ini menggunakan dua macam analisis, metode statistik deskriptif dan statistik inferensial terhadap data yang diperoleh di lapangan. Metode ini bertujuan mendeskripsikan secara lebih mendalam terhadap masing-masing variabel penelitian. Selanjutnya digunakan inferensial untuk melihat kuat lemahnya pengaruh antar variabel bebas dengan variabel terikat, yaitu dengan cara menganalisis terhadap data yang telah diberi skor sesuai dengan skala pengukuran yang telah ditetapkan, melalui suatu formula statistik. Analisis statistik deskriptif dimaksudkan untuk mendeskripsikan variabel ketepatan dana bantuan operasional sekolah, kecukupan dana bantuan operasional sekolah, kesesuaian penggunaan dana bantuan operasional sekolah dan kinerja sekolah dengan menggunakan bantuan tabel frekuensi/presentase. Analisis statistik inferensial dimaksudkan untuk menguji hipotesis, diringkas dalam analisis variabel ditinjau dari mean dan PCA (Principle Component Analysis), analisis regresi, dan uji asumsi klasik.

\section{HASIL PENELITIAN DAN PEMBAHASAN}

\section{Analisis Variabel Ditinjau dari Mean dan PCA (Principle Component Analisis)}

Analisis variable ditinjau dari Mean dan PCA menjelaskan perbandingan antara mean dan rata-rata indikator hasil analisis faktor dengan menggunakan program SPSS. Hal ini dimaksudkan untuk mendeskripsikan setiap indikator yang memberikan kontribusi yang signifikan sebagai pembentuk variabel. Nilai rata-rata yang mencerminkan persepsi responden terhadap indikator penelitian, sedangkan nilai analisis faktor menggambarkan kontribusi indikator dalam membentuk variabel. Persepsi responden terhadap indikator-indikator variabel penelitian ditinjau dari mean dan nilai analisis faktor dapat dilihat pada tabel 1 .

Berdasarkan tabel 1 menunjukkan variable Ketepatan Dana BOS memiliki Mean 4,20, hasil uji nilai PCA menunjukkan bahwa Triwulan 3 dengan nilai 0,941 merupakan indikator penting dan mempunyai nilai tertinggi dalam membentuk variabel Ketepatan Dana BOS. Variabel Kecukupan Dana BOS memiliki Mean 4,06, hasil uji nilai PCA menunjukkan indikator kebutuhan penerima dengan nilai 0,922 merupakan indikator penting dan mempunyai nilai tertinggi dalam membentuk variabel Ketepatan Dana BOS.

Variable Kesesuaian Dana BOS memiliki nilai Mean 4,08, hasil uji nilai PCA menunjukkan bahwa Kebutuhan Sekolah dengan nilai 0,931 merupakan indikator penting dan mempunyai nilai tertinggi dalam membentuk variabel Kesesuaian Dana BOS. Variable Kinerja Sekolah memiliki nilai Mean 4,39, hasil uji nilai PCA menunjukkan bahwa Standar Pendidik dan Tenaga Kependidikan dengan nilai 0,914 merupakan indikator penting dan mempunyai nilai tertinggi dalam membentuk variabel Kinerja Sekolah. 
Jurnal Progres Ekonomi Pembangunan (JPEP)

Volume 5, Nomor 1, Tahun 2020

Page: 47- 57

http://ojs.uho.ac.id/index.php/JPEP

Tabel 1

Perbandingan Nilai Mean dan Analisis Faktor

\begin{tabular}{|c|l|c|c|}
\hline \multirow{2}{*}{ No. } & \multicolumn{1}{|c|}{ Indikator } & Mean & $\begin{array}{c}\text { PCA (Analisis } \\
\text { Faktor) }\end{array}$ \\
\hline \multirow{2}{*}{1} & Ketepatan Dana Bos (X1) & $\mathbf{4 , 2 0}$ & 0,910 \\
& Triwulan 1 (X1.1) & $\mathbf{4 , 2 1}$ & 0,933 \\
& Triwulan 2 (X1.2) & 4,19 & $\mathbf{0 , 9 4 1}$ \\
& Triwulan 3 (X1.3) & 4,20 & 0,914 \\
& Triwulan 4 (X1.4) & 4,20 & 0,806 \\
& Kecukupan Dana BOS (X2) & $\mathbf{4 , 0 6}$ & 0,916 \\
& Sesuai dengan Kebutuhan Sekolah (X2.1) & 4,03 & $\mathbf{0 , 9 2 2}$ \\
& Sesuai dengan jumlah penerima (X2.2) & $\mathbf{4 , 0 9}$ & $\mathbf{0 , 9 3 1}$ \\
& Sesuai dengan kebutuhan penerima (X2.3) & 4,07 & 0,858 \\
& Kesesuaian Dana BOS (X3) & $\mathbf{4 , 0 8}$ & 0,912 \\
& Kebutuhan Sekolah (X3.1) & 4,05 & $\mathbf{4 , 1 0}$ \\
& Rancangan Kegiatan (X3.2) & 4,08 & 0,909 \\
& Laporan Keuangan (X3.3) & $\mathbf{4 , 3 9}$ & 0,878 \\
& Kinerja Sekolah (Y) & 4,33 & 0,871 \\
& Standar Isi (Y1) & 4,26 & $\mathbf{0 , 9 1 4}$ \\
& Standar Proses (Y2) & 4,38 & 0,798 \\
& Standar Kompetensi Lulusan (Y3) & 4,29 & 0,891 \\
& Standar Pendidik dan Tenaga Kependidikan (Y4) & 4,33 & 0,857 \\
& Standar Penilaian Pendidikan (Y5) & 4,29 & 0,810 \\
\hline & Standar Sarana dan Prasarana (Y6) & 4,35 & $\mathbf{4 , 4 4}$ \\
& Standar Pengelolaan (Y7) & & \\
& Standar Pembiayaan (Y8) & & \\
\hline
\end{tabular}

Sumber: Data Primer diolah tahun 2019

\section{Analisis Regresi}

Berdasarkan hasil pengolahan data, Ketepatan Dana BOS, Kecukupan Dana BOS, dan Kesesuaian Dana BOS berpengaruh positif terhadap Kinerja Sekolah. Hal ini dapat dilihat pada hasil pengolahan data dengan menggunakan SPSS pada Tabel 2.

Berdasarkan Tabel 2, maka persamaan regresi berganda yang menyatakan pengaruh ketepatan dana BOS $\left(\mathrm{X}_{1}\right)$, kecukupan dana BOS $\left(\mathrm{X}_{2}\right)$, dan kesesuaian penggunaan dana BOS $\left(\mathrm{X}_{3}\right)$ terhadap kinerja sekolah $(\mathrm{Y})$ dapat dinyatakan sebagai berikut:

$$
\mathrm{Y}=0,794+0,250 \mathrm{X}_{1}+0,326 \mathrm{X}_{2}+0,167 \mathrm{X}_{3}
$$

Tabel 2

Hasil Regresi Linier Berganda

\begin{tabular}{|l|c|c|c|}
\hline \multicolumn{1}{|c|}{ Parameter } & Koefisien & t-statistik & Sig. \\
\hline Konstanta & 0.794 & 7.624 & 0.000 \\
\hline Ketepatan Dana BOS (X1) & 0.250 & 4.473 & 0.000 \\
\hline Kecukupan Dana BOS (X2) & 0.326 & 7,723 & 0.000 \\
\hline Kesesuaian Dana BOS (X3) & 0.167 & 3,232 & 0.001 \\
\hline \multicolumn{3}{r|}{ F-Statistik } & 315,767 \\
\hline \multicolumn{3}{r|}{ Sig. F-Statistik } & 0.0000 \\
\hline \multicolumn{2}{r|}{0,906} \\
\hline
\end{tabular}

Sumber: Data Primer diolah tahun 2019 
Jurnal Progres Ekonomi Pembangunan (JPEP)

Volume 5, Nomor 1, Tahun 2020

Page: 47- 57

http://ojs.uho.ac.id/index.php/JPEP

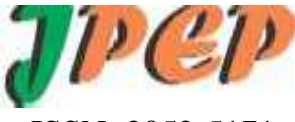

e-ISSN: 2052-5171

Berdasarkan rumus regresi diatas menjelaskan sebagai berikut:

1. Nilai konstanta dalam penelitian ini adalah sebesar 0,796 yang menjelaskan bahwa apabila Ketepatan Dana BOS, Kecukupan Dana BOS, dan Kesesuaian Penggunaan Dana BOS tidak mengalami perubahan atau sama dengan nol, maka Kinerja Sekolah akan konstan sebesar 0,794.

2. Koefisien regresi pada variabel Ketepatan Dana BOS menunjukkan sebesar 0,250. Tanda positif berarti apabila penyaluran dana BOS tepat waktu maka Kinerja Sekolah semakin meningkat, begitu sebaliknya, apabila penyaluran dana BOS tidak tepat waktu maka Kinerja Sekolah akan menurun.

3. Koefisien regresi pada variabel Kecukupan Dana BOS menunjukkan sebesar 0,326. Tanda positif berarti apabila Dana BOS cukup maka Kinerja Sekolah semakin meningkat, begitu sebaliknya, apabila Dana BOS tidak cukup Kinerja Sekolah akan menurun.

4. Koefisien regresi pada variabel Kesesuaian Penggunaan Dana BOS menunjukkan sebesar 0,167 . Tanda positif berarti apabila penggunaan dana BOS sesuai juknis maka kinerja sekolah semakin meningkat, begitu sebaliknya, apabila penggunaan dana BOS tidak sesuai juknis maka kinerja sekolah akan menurun

5. Berdasarkan Tabel 2 menunjukkan bahwa nilai koefisien korelasi (R) adalah sebesar 0,906 yang berarti bahwa keeratan antara variabel $\mathrm{X}_{1}, \mathrm{X}_{2}$, dan $\mathrm{X}_{3}$ terhadap $\mathrm{Y}$ dengan nilai yang mendekati 1. Hal ini menunjukkan bahwa hubungan langsung antara Ketepatan Dana BOS, Kecukupan Dana BOS, dan Kesesuaian Penggunaan Dana BOS terhadap Kinerja Sekolah dikategorikan sangat erat.

6. Nilai Koefisien Determinasi $\left(\mathrm{R}^{2}\right)$, berdasarkan hasil estimasi pada tabel 5.22 dapat dilihat bahwa nilai $\mathrm{R}^{2}$ ( $R$-Square) yaitu sebesar 0,820 dengan persentase sebesar $82 \%$. Hal ini menunjukkan bahwa variasi perubahan terhadap variabel Kinerja Sekolah (Y) yang dijelaskan oleh variabel Ketepatan Dana BOS $\left(\mathrm{X}_{1}\right)$, Kecukupan Dana BOS $\left(\mathrm{X}_{2}\right)$ dan Kesesuaian Penggunaan Dana BOS $\left(\mathrm{X}_{3}\right)$ yaitu sebesar 82,\%, sedangkan 18\% lainnya dari variasi perubahan variabel Kinerja Sekolah (Y) yang dijelaskan oleh variabel lain yang belum termasuk dalam model penelitian ini.

\section{Uji Hipotesis}

\section{Pengaruh Ketepatan Dana BOS Terhadap Kinerja Sekolah}

Berdasarkan Tabel Pengolahan Data, diperoleh bahwa nilai koefisien regresi pengaruh ketepatan dana BOS terhadap kinerja sekolah sebesar 0.250 dan probability sebesar 0.000 . Nilai signifikan probability sebesar 0.000 lebih kecil dari nilai alpha 5\% (0.05), sehingga dapat disimpulkan bahwa pada tingkat keyakinan 95\% dapat dinyatakan bahwa ketepatan dana BOS berpengaruh signifikan terhadap kinerja sekolah.

\section{Pengaruh Kecukupan Dana BOS Terhadap Kinerja Sekolah}

Berdasarkan Tabel Pengolahan Data, diperoleh bahwa nilai koefisien regresi pengaruh Kecukupan Dana BOS terhadap Kinerja Sekolah sebesar 0.326 dan probability sebesar 0.000 . Nilai signifikan probability sebesar 0.000 lebih kecil dari nilai alpha 5\% (0.05), sehingga dapat disimpulkan bahwa pada tingkat keyakinan 95\% dapat dinyatakan bahwa Kecukupan Dana BOS berpengaruh signifikan terhadap kinerja sekolah.

\section{Pengaruh Kesesuaian Penggunaan Dana BOS Terhadap Kinerja Sekolah}

Berdasarkan Tabel Pengolahan Data, diperoleh bahwa nilai koefisien regresi pengaruh Kesesuaian Penggunaan Dana BOS terhadap kinerja sekolah sebesar 0.167 dan probability sebesar 0.001. Nilai signifikan probability sebesar 0.000 lebih kecil dari nilai alpha 5\% (0.05), sehingga dapat disimpulkan bahwa pada tingkat keyakinan 95\% dapat dinyatakan bahwa Kesesuaian Penggunaan Dana BOS berpengaruh signifikan terhadap kinerja sekolah. 
Jurnal Progres Ekonomi Pembangunan (JPEP)

Volume 5, Nomor 1, Tahun 2020

Page: $47-57$

http://ojs.uho.ac.id/index.php/JPEP

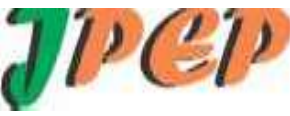

e-ISSN: 2052-5171

\section{Pembahasan}

1. Pengaruh Ketepatan Dana Bantuan Operasional Sekolah terhadap terhadap kinerja Sekolah Menengah Kejuruan Kabupaten Konawe

Berdasarkan hasil analisis statistik menunjukkan bahwa ketepatan dana bantuan operasional sekolah menengah kejuruan se Kabupaten Konawe diperoleh nilai koefisien sebesar 0,250 dan nilai signifikan 0,000 atau dibawah nilai 0,05, sehingga dapat disimpulkan bahwa pada tingkat keyakinan 95\% dapat dinyatakan bahwa ketepatan dana BOS berpengaruh signifikan terhadap kinerja sekolah. Hal ini menunjukkan bahwa secara parsial ketepatan dana bantuan operasional sekolah berpengaruh positif dan signifikan terhadap kinerja sekolah menengah kejuruan se-Kabupaten Konawe.

Hasil analisis tersebut dapat dijelaskan berdasarkan data pada tabel 1 bahwa rerata persepsi responden atas pengaruh ketepatan dana BOS pada Kinerja Sekolah adalah 4,20 (kategori positif/baik). Pada variable Ketepatan Dana BOS, yang terjadi pada indikator Triwulan 1 yang dominan dengan Hasil Mean dari indikator tersebut menunjukkan rerata 4,21. Hasil uji nilai PCA untuk variabel Ketepatan Dana BOS terlihat bahwa Triwulan 3 dengan nilai 0,941 merupakan indikator penting dan mempunyai nilai tertinggi dalam membentuk variabel Ketepatan Dana BOS. Hal tersebut dapat disimpulkan bahwa seharusnya sekolah lebih meningkatkan pemanfaatan dana Triwulan 3 menjadi faktor utama yang membentuk Variabel Ketepatan Dana BOS.

Meskipun hasil penelitian variabel Ketepatan Dana BOS menunjukkan hasil positif (baik), masih perlu meningkatkan ketepatan penggunaan dana BOS pada Triwulan 2. Hal ini karena memiliki mean terendah $(4,19)$, sementara hasil uji nilai PCA menjukkan nilai 0,933 yang berarti bahwa indikator Triwulan 2 menempati peringkat kedua setelah indikator Triwulan 3 yang menempati peringkat paling penting.

Berdasarkan hasil analisis di atas, dapat dikatakan bahwa ketepatan dana bantuan operasional sekolah jika dilaksanakan sesuai dengan waktu pencairan maka akan meningkatkan kinerja sekolah. Menurut Asnawi (2013), jika kebijakan bantuan operasional sekolah tersebut mencapai hasil (akibat) yang diharapkan atau mencapai tujuan dari diadakannya kegiatan-kegiatan yang dilakukan.

Hasil penelitian Dirjen Anggaran, Kemenkeu (2015), bahwa ketepatan dana bantuan operasional sekolah adalah persoalan bagaimana ketepatan waktu (efektivitas) penyaluran dana bantuan operasional sesuai dengan petunjuk teknis dan petunjuk pelasanaan dana tersebut.

Hasil penelitian Diputra (2011) menyatakan bahwa ketepatan dana bantuan operasional sekolah berpengaruh secara signifikan baik secara simultan maupun parsial terhadap kinerja guru dan prestasi belajar siswa di sekolah dasar negeri di Kota Denpasar. Begitu juga hasil penelitian Asnawi (2013) yang menyatakan bahwa ketepatan dana bantuan operasional sekolah berpengaruh signifikan dengan kinerja SMP Negeri 6 Kabupaten Bintan. Demikian pula Ningsih (2017) dan Soulisa (2017) bahwa ketepatan dana bantuan operasional sekolah berpengaruh signifikan terhadap kinerja sekolah dasar di Kecamatan Tebing Tinggi Barat Kabupaten Kepulauan Meranti dan sekolah negeri di kecamatan Palu Timur.

\section{Pengaruh Kecukupan Dana Bantuan Operasional Sekolah terhadap Kinerja Sekolah Menengah Kejuruan Kabupaten Konawe}

Berdasarkan hasil analisis statistik menunjukkan bahwa kecukupan dana bantuan operasional sekolah menengah kejuruan se Kabupaten Konawe diperoleh nilai koefisien sebesar 0,326 dan nilai signifikan 0,000 atau dibawah nilai 0,05, sehingga dapat disimpulkan bahwa pada tingkat keyakinan $95 \%$ dapat dinyatakan bahwa kecukupan dana BOS berpengaruh signifikan terhadap kinerja sekolah. Hal ini menunjukkan bahwa secara parsial 
Jurnal Progres Ekonomi Pembangunan (JPEP)

Volume 5, Nomor 1, Tahun 2020

Page: 47- 57

http://ojs.uho.ac.id/index.php/JPEP

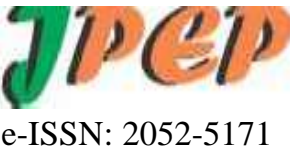

kecukupan dana bantuan operasional sekolah berpengaruh positif dan signifikan terhadap kinerja sekolah menengah kejuruan se-Kabupaten Konawe.

Hasil analisis tersebut dapat dijelaskan berdasarkan data pada Tabel 1 bahwa rerata persepsi responden atas pengaruh ketepatan dana BOS pada Kinerja Sekolah adalah 4,06 (kategori positif/baik). Pada variable Kecukupan Dana BOS, yang terjadi pada indikator sesuai dengan jumlah penerima yang dominan dengan Hasil Mean dari indikator tersebut menunjukkan rerata 4,09. Hasil uji nilai PCA untuk variabel Ketepatan Dana BOS terlihat indicator sesuai dengan kebutuhan penerima dengan nilai 0,922 merupakan indikator penting dan mempunyai nilai tertinggi dalam membentuk variabel Ketepatan Dana BOS, Hal tersebut dapat disimpulkan bahwa seharusnya sekolah lebih menekankan pada indicator sesuai dengan kebutuhan penerima yang menjadi faktor utama yang membentuk Variabel Ketepatan Dana BOS.

Meskipun hasil penelitian variabel Kecukupan Dana BOS menunjukkan hasil positif (baik), masih perlu meningkatkan kecukupan indikator sesuai dengan kebutuhan sekolah. Hal ini karena memiliki mean terendah $(4,03)$, demikian pulan hasil uji nilai PCA menjukkan nilai 0,806 yang menempati peringkat ketiga.

Berdasarkan analisis di atas, dapat dikatakan bahwa kecukupan dana bantuan operasional sekolah akan meningkatkan kinerja sekolah. Menurut Asnawi (2013) menyatakan bahwa kecukupan dana bantuan operasional sekolah berpengaruh signifikan dengan kinerja SMP Negeri 6 Kabupaten Bintan.

Hasil penelitian Dirjen Anggaran, Kemenkeu (2015), bahwa ketepatan dana bantuan operasional sekolah adalah persoalan bagaimana ketepatan waktu (efektivitas) penyaluran dana bantuan operasional sesuai dengan petunjuk teknis dan petunjuk pelaksanaan dana tersebut.

\section{Pengaruh Kesesuaian Dana Bantuan Operasional Sekolah terhadap Kinerja Sekolah Menengah Kejuruan Kabupaten Konawe}

Berdasarkan hasil analisis statistik menunjukkan bahwa kesesuaian dana bantuan operasional sekolah menengah kejuruan se Kabupaten Konawe diperoleh nilai koefisien sebesar 0,167 dan nilai signifikan 0,001 atau dibawah nilai 0,05, sehingga dapat disimpulkan bahwa pada tingkat keyakinan 95\% dapat dinyatakan bahwa ketepatan dana BOS berpengaruh signifikan terhadap kinerja sekolah. Hal ini menunjukkan bahwa secara parsial kesesuaian dana bantuan operasional sekolah berpengaruh positif dan signifikan terhadap kinerja sekolah menengah kejuruan se-Kabupaten Konawe.

Hasil analisis tersebut dapat dijelaskan berdasarkan data pada Tabel 1 bahwa rerata persepsi responden atas pengaruh kesesuaian dana BOS pada Kinerja Sekolah adalah 4,08 (kategori positif/baik). Pada variable Kesesuaian Dana BOS, yang terjadi pada indikator Rancangan Kegiatan yang dominan dengan Hasil Mean dari indikator tersebut menunjukkan rerata 4,10. Hasil uji nilai PCA untuk variabel Kesesuaian Dana BOS terlihat bahwa Kebutuhan Sekolah dengan nilai 0,931 merupakan indikator penting dan mempunyai nilai tertinggi dalam membentuk variabel Kesesuaian Dana BOS, Hal tersebut dapat disimpulkan bahwa seharusnya sekolah lebih meningkatkan Kebutuhan Sekolah yang memiliki nilai rata rata terencah $(4,05)$ menjadi faktor utama yang membentuk Variabel Kesesuaian Dana BOS.

Berdasarkan analisis di atas, dapat dikatakan bahwa kesesuaian penggunaan dana bantuan operasional sekolah akan meningkatkan kinerja sekolah. Menurut Asnawi (2013), bahwa kesesuaian penggunaan dana bantuan operasional sekolah berpengaruh signifikan dengan kinerja SMP Negeri 6 Kabupaten Bintan. Hasil penelitian ini didukung dengan penelitian Suhelmy (2016); Ningsih (2017); Soulisa (2017); dan Saputra (2017). 
Jurnal Progres Ekonomi Pembangunan (JPEP)

Volume 5, Nomor 1, Tahun 2020

Page: 47- 57

http://ojs.uho.ac.id/index.php/JPEP

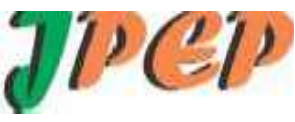

e-ISSN: 2052-5171

\section{KESIMPULAN DAN SARAN}

\section{Kesimpulan}

Berdasarkan hasil penelitian dan pembahasan tentang Pengaruh Ketepatan Dana, Kecukupan Dana, dan Kesesuaian Penggunaan Dana Bantuan Operasional Sekolah terhadap Kinerja Sekolah Menengah Kejuruan di Kabupaten Konawe maka dapat ditarik beberapa kesimpulan sebagai berikut:

1. Ketepatan dana bantuan operasional sekolah berpengaruh secara positif dan signifikan terhadap kinerja sekolah menengah kejuruan Kabupaten Konawe. Artinya, semakin tepat dana bantuan operasional sekolah diberikan, akan semakin meningkatkan kinerja sekolah menengah kejuruan di Kabupaten Konawe.

2. Kecukupan dana bantuan operasional sekolah berpengaruh secara positif dan signifikan terhadap kinerja sekolah menengah kejuruan Kabupaten Konawe. Artinya, apabila dana bantuan operasional sekolah diberikan dengan cukup, maka akan meningkatkan kinerja sekolah menengah kejuruan di Kabupaten Konawe.

3. Kesesuaian penggunaan dana bantuan operasional sekolah berpengaruh secara positif dan signifikan terhadap kinerja sekolah menengah kejuruan Kabupaten Konawe. Artinya, apabila dana bantuan operasional digunakan sesuai dengan regulasi (petunjuk teknis), maka akan semakin meningkatkan kinerja sekolah menengah kejuruan di Kabupaten Konawe.

\section{Saran}

Berdasarkan hasil dan kesimpulan penelitian, maka peneliti menyampaikan saran sebagai berikut:

1. Untuk meningkatkan ketepatan dana bantuan operasional sekolah dalam rangka meningkatkan kinerja sekolah, maka perlu perencanaan lebih matang dalam memanfaatkan dana bantuan operasional sekolah pada triwulan 2 .

2. Untuk meningkatkan kecukupan dana bantuan operasional sekolah dalam rangka meningkatkan kinerja sekolah, maka perlu diidentifikasi kebutuhan sekolah berdasarkan prioritas untuk mencapai standar Pendidikan.

3. Untuk meningkatkan kesesuaian dana bantuan operasional sekolah dalam rangka meningkatkan kenerja sekolah, maka perlu mengutamakan kebutuhan sekolah yang menjadi prioritas kegiatan.

4. Penelitian selanjutnya sebaiknya menggunakan sampel besar dengan memperluas objek penelitian tidak hanya pada sekolah menengah kejuruan, tetapi sekolah menengah atas ataupun sekolah menengah pertama dan sekolah dasar sebagai konsekuensi penerima bantuan operasioanl sekolah oleh pemerintah.

\section{DAFTAR PUSTAKA}

Asnawi, Aulia Prihatin. 2013. Evaluasi Program Bantuan Operasional Sekolah (BOS) Dana Anggaran Pendapatan Belanja Negara (APBN) Tahun 2012 (Studi pada Sekolah Menengah Pertama (SMP) Negeri 6 Kabupaten Bintan. Skripsi, Universitas Maritim Raja Haji, Tanjungpinang.

Badallah, Ridwan. 2017. Peran Tokoh Masyarakat dalam Menanggulangi Anak Putus Sekolah di Kota Kendari. National Research Policy, Pusat Penelitian Kebijakan Pendidikan, Badan Penelitian dan Pengembangan, Kemendikbud.

Diputra, Gde Indra Surya. 2011. Analisis pengaruh dana Bantuan Operasional Sekolah (BOS), Rata-rata Masa Kerja Guru, dan Rasio Siswa Tidak Mampu terhadap Prestasi Belajar Siswa Sekolah Dasar Negeri Di kota Denpasar. http://ojs.unud.ac.id (8/12/2013). 
Jurnal Progres Ekonomi Pembangunan (JPEP)

Volume 5, Nomor 1, Tahun 2020

Page: $47-57$

http://ojs.uho.ac.id/index.php/JPEP

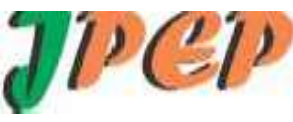

e-ISSN: 2052-5171

Direktorat jenderal Anggaran kementerian Keuangan Republik Indonesia.2015. Petunjuk Teknis Pengelolaan Dana batuan Operasional sekolah. Jakarta.

Hendarman. 2018. Revolusi Kinerja Kepala sekolah. Jakarta: Indeks.

Jayatri, Monika. 2012. Analisis Pengelolaan Dana Bantuan Operasional Sekolah (BOS) di SMPN 11 Yogyakarta dan SMPN 1 Purworejo. Skripsi, Universitas Indonesia.

Kartowiyono. 2019. Pengaruh Dana BOS Terhadap Kinerja Sekolah (Studi pada SMK Kabupaten Konawe). Kendari. Universitas Haluoleo.

Kementerian Pendidikan dan Kebudayaan.2014. Petunjuk Teknis Bantuan Operasional Sekolah (BOS).Jakarta : Direktorat Pembinaan Sekolah Menengah Atas, Dikdasmen.

Kementerian Pendidikan dan Kebudayaan. 2017. Petunjuk Teknis Bantuan Operasional Sekolah (BOS). Jakarta: Direktorat Pembinaan Sekolah Menengah Atas, Dikdasmen.

Mangkunegara, A.A. Anwar Prabu. 2014. Perencanaan dan Pengembangan Sumber Daya Manusia. Bandung: Aditama.

Marliani, Septi. 2015. Kesesuaian Rancangan Kegiatan dan Anggaran Sekolah (RKAS) dengan Laporan Pertanggungjawaban Tahun 2014/2015 di SD Negeri 2 Jati Kecamatan Binangun Kabupaten Cilacap.Tesis: UNY.

Mulyasa, H.E. 2007. Menjadi Guru Profesional. Bandung: Rosda.

Ningsih, Septia. 2017. Implementasi Dana Bantuan Operasional Sekolah (BOS) dalam Penyelenggaraan Pendidikan Sekolah Dasar Kecamatan Tebing Tinggi Barat, Kabupaten Kepulauan Meranti, Tahun 2015. JOM FISIP Vol. 4, No. 1, 2017.

Peraturan Pemerintah Nomor 19 Tahun 2005.Standar Pendidikan Nasional. Jakarta.

Perdana, Saka. 2016. Implementasi Kebijakan Dana Bantuan Operasional Sekolah (BOS) di SD Negeri Bekelan, Kulonprogo. Jurnal Kebijakan Pendidikan Edisi 7, Vol. V. Tahun 2016.

Rasto. 2012. Mengukur Kinerja Sekolah. UI.

Saputra, Jhony. 2017. Pengaruh Kejelasan sasaran Anggaran, Kinerja Manajerial, dan Pelaporan/Pertanggungjawaban Anggaran terhadap Akuntabilitas Kinerja Instansi Pemerintah.Thesis.

Sedan, Wensislaus. 2013. Evaluasi Pelaksanaan Program Bantuan Operasional Sekolah (BOS) Sekolah Dasar Negeri/Swasta di Kabupaten Sumba Barat Daya Tahun Anggaran 2012. Jakarta: Universitas Terbuka.

Solimun, dkk.. 2017. Metode Statistika Multivariat; Pemodelan Persamaan Struktural (SEM) Pendekatan WarpPLS.Malang: UB Press

Soulisa, Nurmala Sari. 2017. Evaluasi Kebijakan Dana Bantuan Operasional Sekolah pada Sekolah Negeri di Kecamatan Palu Timur. Thesis.

Sugiono, Risca Kurnuasari Agus; Andiana; dan Kurrohman, Taufik. 2015. Pengaruh Ketepatan Dana, Kecukupan Dana, dan Sasaran Penggunaan Dana Bantuan Operasional Sekolah terhadap Peningkatan Prestasi Belajar Siswa di Kabupaten Jember. Jember: UNEJ.

Suhelmy, dkk.. 2016. Pengaruh Dana Bantuan Operasional Sekolah (BOS) dan Dana Penunjang Pendidikan (DPP) terhadap Kinerja Sekolah. Jurnal Magister Akuntansi Pascasarjana Universitas Syiah Kuala, pp. 67 - 71.

Undang-Undang Nomor 20 Tahun 2003.Sistem Pendidikan Nasional. Jakarta.

Utama, Daniel Aditya. 2013. Pengaruh Transparansi, Akuntabilitas, dan Responsibilitas Pengelolaan Keuangan Sekolah terhadap Kinerja Guru di SMP Negeri Eks-RSBI SeKota Semarang. Tesis. Semarang: Jurusan Pendidikan Ekonomi Universitas Negeri Semarang. 